Vol. 10 (2001): 261-276.

\title{
Ground beetle (Coleoptera, Carabidae) diversity in Finnish arable land
}

\author{
Juha Helenius \\ Department of Applied Biology, PO Box 27, FIN-00014 University of Helsinki, Finland, \\ e-mail: juha.helenius@helsinki.fi
}

Jarmo K. Holopainen

MTT Agrifood Research Finland, Plant Production Research, Plant Protection, FIN-31600 Jokioinen, Finland.

Current address: Department of Ecology and Environmental Science, University of Kuopio, PO Box 1627,

FIN-70211 Kuopio, Finland

Erja Huusela-Veistola

MTT Agrifood Research Finland, Plant Production Research, Plant Protection, FIN-31600 Jokioinen, Finland

\section{Sirpa Kurppa}

MTT Agrifood Research Finland, Plant Production Research, Plant Protection, FIN-31600 Jokioinen, Finland.

Current address: MTT Agrifood Research Finland, Environmental Research, FIN-31600 Jokioinen, Finland

Pia Pokki, Anna-Liisa Varis

Department of Applied Biology, PO Box 27, FIN-00014 University of Helsinki, Finland

Carabid data compiled from six independent studies, consisting of 97799 individuals trapped by pitfalls from Finnish agricultural fields and identified to 111 species were analyzed. Shannon-Wiener $\mathrm{H}^{\prime}$ diversity index was typically around 2.5 and expected species number rarefied to 600 trapped individuals was typically around 30 species. The five most abundant species accounted for $42 \%$ of the total catch, and the thirty most abundant species made up $98 \%$ of the total catch. Percentage similarities among the assemblages by PS-index were from 16\% to 48\%. In comparison to published data about carabid diversity in boreal forests, which form the dominating habitat matrix in which Finnish farmland is embedded as relatively small patches, arable fields harbor more species rich assemblages, with more even rank-abundance distributions but variable species composition. Importance of landscape (regional) level, instead of spatial level of crop fields, in understanding carabid diversity in farmland is discussed. Inclusion of carabids into monitoring schemes of agro-biodiversity at landscape level is suggested.

Key words: Carabid fauna, agricultural fields, species richness, evenness, similarity, agro-biodiversity, monitoring 


\section{Helenius, J. et al. Ground beetle diversity}

\section{Introduction}

Ground beetles (Coleoptera, Carabidae) are ground dwelling, polyphagous or predatory insects, abundant in many kinds of terrestrial habitats. The larvae are subterranean predators. Carabids may be collected in large numbers using pitfall traps, and due to their abundance and species richness (more than 40000 species described) they are popular objects of study. They are abundant in agricultural fields all over the world and may be important natural enemies of agricultural pests. Thiele (1977) investigated the carabids associated with European agricultural crops. For Fennoscandia and Denmark, a comprehensive key for identification, with short descriptions of biology, is available from Lindroth (1985, 1986). Our aim is not to present a review of the extensive literature of agro-carabidology. Among many excellent reviews, see e.g. Lövei and Sunderland (1996), or Kromp (1999).

In 1956, Wishart et al. estimated that predatory beetles destroyed $70 \%$ of cabbage root fly eggs, and Hughes (1959) confirmed that carabids were mainly responsible for this. Potts and Vickerman (1974) suggested that polyphagous predators such as carabids (but also some rove beetles (Staphylinidae) and many spiders) are important predators of aphids in cereal ecosystems. In decades following these reports, applied research into the role of carabids in agroecosystems has proliferated. Kromp (1999) concludes his review on this aspect by asking for more studies that would quantify predation and pest control in open-field conditions, and emphasizing that carabids are only one component in the natural enemy complexes in crop fields. Most of the studies from which our data originates were originally motivated by the beneficial role of carabids.

In Finland, Varis and colleagues initiated agro-carabidology by studying egg predation on cabbage root flies (Varis 1982), and abundance and seasonal occurrence of adult carabids in some crops in southern Finland (Varis et al. 1984). She and her students then continued with studies on various applied aspects: studies on trapping methods (Holopainen and Varis 1986, Holopainen 1992), on predation of root flies (Varis 1989) and cereal aphids (Helenius 1990, Holopainen and Helenius 1992), on abundance and reproduction (Helenius et al. 1995, Helenius 1995), and on pollution effects (Holopainen et al. 1995) in agroecosystems. Vasarainen and Kurppa (1996) and Huusela-Veistola (1996, 2000) continued with studies into effects of cultivation techniques and pesticide use on carabids. All these studies serve in describing carabid diversity, but Kinnunen (1999, see also Kinnunen et al. 1996, Kinnunen and Tiainen 1999, Kinnunen et al. 2001) was the first who focused into understanding the patterns, especially in relation to spatial scales, in communities of carabids in Finnish farmland.

Apart from what is listed above, we do not know of other studies that would deal with diversity of carabids in agricultural fields in Finland. As only $9 \%$ of the land cover is in agricultural use, and practically all the rest is under forest cover, Finnish biologists have traditionally focused into forest systems. However, Kinnunen's (1999) work now provides a landmark for further studies on community ecological aspects of carabid diversity in agricultural land in Finland.

In this report we do not aim into a community ecological analysis. The basic idea of this study was to pull together our various pitfall data on carabids in many regions and over a 17 years time span in Finnish agroecosystems, in order to provide a reference for future surveys of species diversity (along the lines of Duelli et al. 1999). We believe that such reference, even if unperfected in many respects, may be useful especially for future studies monitoring biodiversity and agroecosystem change in Finland. 
Vol. 10 (2001): 261-276.

\section{Material and methods}

\section{Study areas, data sets and trapping methods}

All data were from pitfall trapping studies. Altogether 23 subsets of data from 1978 until 1994 were used, and the pooled (total) number of pitfall samples was 21344. These studies covered a geographic area ranging from the Southwest to the Northeast of Finland (Table 1, Fig. 1).
Regional range is from hemiboreal to southern boreal phytogeographical zones (Ahti et al. 1968) and from 1.25 to $0.95 \mathrm{k}^{\circ} \mathrm{C} \mathrm{DD}$ above $5^{\circ} \mathrm{C}$ in the length of the thermal growing season.

Pitfall traps varied moderately in design (Table 2). All studies used circular cups, in which the diameter range was 80 to $100 \mathrm{~mm}$. The most common collecting fluid was water with detergent and sometimes $\mathrm{NaCl}$ as preservative added. In one study, ethylene glycol, and in another, formalin solution was used. A lid to shade the trap was sometimes used (Table 2). Traps

Table 1. Data sets and study sites (from North to South, see also Fig. 1). Windows of Day Degrees are indicated, and the total catch of carabids given, for the sub-sets of the data.

\begin{tabular}{|c|c|c|c|c|c|}
\hline Data set & Author & Year & Trapping period & $\mathrm{DD}_{\text {range }}{ }^{1}$ & $\begin{array}{l}\text { Total number } \\
\text { of specimens }\end{array}$ \\
\hline Siilinjärvi & Holopainen & 1991 & 4 June - 20 August & $74.3-876.9$ & 8722 \\
\hline Outokumpu & Pokki & $\begin{array}{l}1990 \\
1991 \\
1993 \\
1994 \\
\text { Total }\end{array}$ & $\begin{array}{l}9 \text { May - } 20 \text { July } \\
15 \text { May - } 21 \text { July } \\
12 \text { May - 1 July } \\
18 \text { May - 39 June } \\
\text {. }\end{array}$ & $\begin{array}{l}76.3-580.6 \\
20.2-556.7 \\
87.7-375.0 \\
66.0-322.2 \\
20.2-580.6\end{array}$ & $\begin{array}{r}3062 \\
2315 \\
1057 \\
726 \\
7160\end{array}$ \\
\hline Jokioinen & Kurppa & $\begin{array}{l}1991 \\
1992 \\
1993 \\
1994 \\
\text { Total }\end{array}$ & $\begin{array}{l}31 \text { May - } 24 \text { September } \\
5 \text { May - 26 August } \\
7 \text { May - } 1 \text { September } \\
6 \text { May - } 25 \text { August } \\
\text {. }\end{array}$ & $\begin{array}{r}66.7-1087.5 \\
18.8-1106.9 \\
102.2-1076.2 \\
51.0-1047.3 \\
18.8-1106.9\end{array}$ & $\begin{array}{r}2442 \\
3666 \\
3018 \\
1534 \\
10660\end{array}$ \\
\hline SW Finland & Huusela-Veistola & 1991 & 17 June - 5 July & $81.9-510.9$ & 11860 \\
\hline Viikki-I & Helenius & $\begin{array}{l}1983 \\
1984 \\
1985 \\
1986 \\
1988 \\
1989 \\
1990 \\
1991 \\
\text { Total }\end{array}$ & $\begin{array}{l}26 \text { May - } 21 \text { July } \\
18 \text { May - } 20 \text { July } \\
30 \text { May - } 5 \text { September } \\
29 \text { May - } 7 \text { August } \\
13 \text { May - } 22 \text { September } \\
23 \text { May - } 19 \text { June } \\
9 \text { May - 16 September } \\
13 \text { May-4 August } \\
.\end{array}$ & $\begin{array}{r}132.3-792.4 \\
58.3-757.4 \\
66.5-1160.3 \\
189.4-1040.7 \\
52.3-1533.8 \\
152.6-394.5 \\
144.1-1320.9 \\
40.7-807.7 \\
40.7-1533.8\end{array}$ & $\begin{array}{r}5675 \\
3703 \\
1102 \\
2595 \\
2812 \\
555 \\
11346 \\
8551 \\
36339\end{array}$ \\
\hline Viikki-II & Varis & $\begin{array}{l}1978 \\
1979 \\
1982 \\
1984 \\
1985 \\
\text { Total }\end{array}$ & $\begin{array}{l}17 \text { May - } 14 \text { September } \\
10 \text { May - } 12 \text { September } \\
31 \text { May - } 20 \text { August } \\
11 \text { June - } 26 \text { July } \\
2 \text { June - } 27 \text { July } \\
\text {. }\end{array}$ & $\begin{array}{r}29.4-1195.5 \\
8.1-1362.4 \\
134.0-982.7 \\
359.4-815.1 \\
160.6-715.8 \\
8.1-1362.4\end{array}$ & $\begin{array}{r}8348 \\
9170 \\
5633 \\
570 \\
997 \\
24718\end{array}$ \\
\hline Total & & . & . & . & 99459 \\
\hline
\end{tabular}

${ }^{1}$ Range of Day Degrees accumulated from the start to end of the trapping period, obtained from the nearest meteorological station as accumulation of degrees above $5^{\circ} \mathrm{C}$ from the onset of the thermal growing season. 


\section{Helenius, J. et al. Ground beetle diversity}

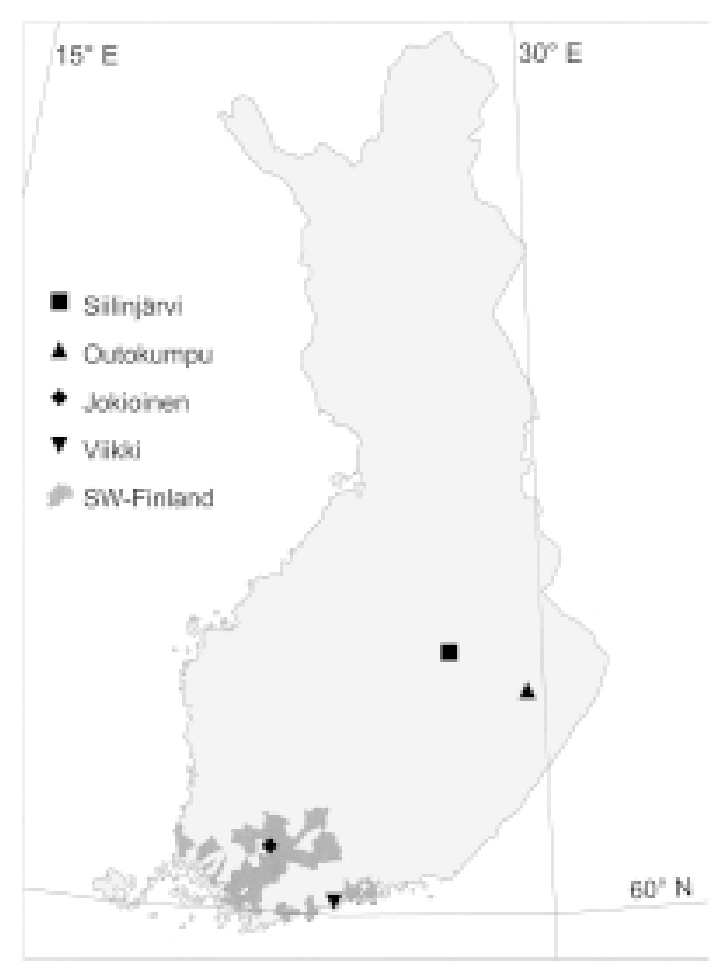

Fig. 1. Map of sampling locations for the six data sets of the study.

were emptied at intervals of two days to two weeks. Trapping effort is expressed as the total number of trap-days cumulated from the onset to the emptying of the last trap for each of the data sets (Table 2).

The Siilinjärvi data $\left(63^{\circ} 03^{\prime} \mathrm{N}, 27^{\circ} 39^{\prime} \mathrm{E}\right)$ are from the study by Holopainen et al. (1995) who conducted pitfall trapping from 15 spring barley fields and one oat field in the Siilinjärvi municipality. The original aim in this study was to relate carabid diversity to soil properties and to foliar fluoride content. Holopainen (1992) described details of the trapping method, and an independent analysis of species diversity was given by Holopainen et al. (1995).

The 1990-1991 subset of Outokumpu data are from an unpublished M.Sc. study by Pokki (Pia Pokki, unpublished MSc thesis, University of Helsinki 1992), which aimed to describe the local diversity of carabids in arable land. Pit- fall trapping was conducted in 8 spring barley fields in the neighboring municipalities of $\mathrm{Ou}$ tokumpu (3 fields; $62^{\circ} 42^{\prime} \mathrm{N}, 2^{\circ} 05^{\prime} \mathrm{E}$ ), Liperi (2 fields; 62 $36^{\prime}$ N, $29^{\circ} 14^{\prime}$ E), Joensuu (one field; $62^{\circ} 36^{\prime} \mathrm{N}, 29^{\circ} 34^{\prime} \mathrm{E}$ ), and Kontiolahti (2 fields, $\left.62^{\circ} 45^{\prime} \mathrm{N}, 29^{\circ} 49^{\prime} \mathrm{E}\right)$. In each field, three trap stations of two traps $2 \mathrm{~m}$ apart were established at $30 \mathrm{~m}$ intervals. The 1993-1994 subset of Outokumpu data is from an unpublished study by Pokki and Helenius, in which the effect on carabid activity-density of undersowing with clover or ryegrass was investigated. Trapping was conducted in spring barley fields in Outokumpu (4 fields) and in Liperi (4 fields). The trapping method was the same as for the 1990-1991 Outokumpu data.

The Jokioinen data are from a study by Kurppa and Vasarainen (Vasarainen and Kurppa 1996), in which activity densities of carabids were compared between various crop rotations and between organic and conventional production. All the data are from Yöni-farm in Jokioinen $\left(60^{\circ} 48^{\prime} \mathrm{N}, 23^{\circ} 28^{\prime} \mathrm{E}\right)$, from 14 fields. In these fields, according to the crop rotation scheme, the crops were spring barley (either with or without next year's ley undersown), winter rye, an oatpea mixture (traditional 'mixed cereal'), ley, open fallow, or a weedy field uncultivated since the late 1980s. In the middle of each field, five pitfall traps in $10 \mathrm{~m}$ intervals were emptied every two weeks.

The SW-Finland data are from an unpublished study by Kurppa and Huusela-Veistola. In this study, 127 arable farms in around South and Southwest of Finland were sampled, and pitfall trapping conducted in cereal fields on 43 farms, in sugar beet fields on 49 farms, and in spring rape fields on 35 farms (Fig. 1). Each field was sampled by 10 traps. These were in two sets of five traps, each of the five at $10 \mathrm{~m}$ intervals in a row. The traps were run for a two week period. The trapping periods were set to weeks 23 to 25 in cereal fields, 25 to 27 in sugar beet fields and to weeks 26 to 28 in spring rape fields.

The Viikki-I data are from studies on epigeal predators (Helenius 1990) in spring-sown cereal or seed legume crops on Viikki Experimental 
Vol. 10 (2001): 261-276.

Table 2. Details of pitfall trapping.

\begin{tabular}{|c|c|c|c|c|c|}
\hline Data set & Year & $\begin{array}{c}\text { Effort } \\
\text { (trap-days) }\end{array}$ & $\begin{array}{l}\text { Diameter } \\
(\mathrm{mm})\end{array}$ & Collecting fluid & Lid on trap \\
\hline Siilinjärvi & 1991 & 1155 & 90 & water+detergent & Aluminium \\
\hline \multirow[t]{4}{*}{ Outokumpu } & 1990 & 3108 & 100 & water+detergent+salt & no \\
\hline & 1991 & 2814 & “ & “ & “ \\
\hline & 1993 & 2016 & “ & “ & “ \\
\hline & 1994 & 1692 & “ & $"$ & “ \\
\hline \multirow[t]{4}{*}{ Jokioinen } & 1991 & 5060 & “ & water+detergent+salt & Plastic foil \\
\hline & 1992 & 6335 & “ & $“$ & “ \\
\hline & 1993 & 6055 & “ & “ & “ \\
\hline & 1994 & 5590 & “ & “ & “ \\
\hline SW Finland & 1991 & 17780 & 95 & “ & “ \\
\hline \multirow[t]{8}{*}{ Viikki-I } & 1983 & 8064 & 80 & water+detergent & no \\
\hline & 1984 & 1608 & “ & “ & “ \\
\hline & 1985 & 720 & 68 & $50 \%$ ethylene glycol & “ \\
\hline & 1986 & 1680 & 80 & water+detergent & no \\
\hline & 1988 & 4848 & 100 & “ & “ \\
\hline & 1989 & 800 & “ & water+detergent+salt & no \\
\hline & 1990 & 3808 & “ & “ & no \\
\hline & 1991 & 1664 & “ & “ & no \\
\hline \multirow[t]{5}{*}{ Viikki-II } & 1978 & 7680 & 80 & dry / $2 \%$ formalin+det. & Plastic foil \\
\hline & 1979 & 4000 & “ & “ & “ \\
\hline & 1982 & 2916 & “ & water+detergent & no \\
\hline & 1984 & 1104 & “ & “ & “ \\
\hline & 1985 & 1320 & “ & “ & “ \\
\hline Total & \multicolumn{3}{|c|}{91817 trap days } & & \\
\hline
\end{tabular}

Farm $\left(60^{\circ} 13^{\prime} \mathrm{N}, 2^{\circ} 02^{\prime}\right.$ E) in Helsinki. For summaries see Helenius (1991a). In the 1983 experiment, the crops were oats, an oat-faba bean mixture and faba bean alone, in which pitfall trapping was conducted in 8 plots, with 16 traps per plot. Half of the traps were operated within $5 \mathrm{~m}$ $\times 5 \mathrm{~m}$ enclosures, enclosed by steel strip $200 \mathrm{~mm}$ high, buried $50 \mathrm{~mm}$ into the soil (see Helenius 1990). In the 1984 experiment, the crops were also monocrops or mixtures of oats and faba bean. Pitfall trapping was conducted in 24 plots, one trap per plot. One half of the traps were operated within egress-only plots, and the other half within plots surrounded by ingress-only trenches (ca. $8 \mathrm{~cm}$ deep trenches, Helenius 1990).

In the 1985 experiment, the crops were oats and an oat-faba bean mixture. Trapping was conducted in 12 plots, 2 traps per plot. A quarter of the traps were in open plots, another quarter in plots enclosed by an egress-only trench (trenches as in 1984) for the whole period, a further quarter in plots enclosed by egress-only trenches until June 24, and the rest in plots trenched after June 24. In the 1986 experiment, the crops were oats and an oat-faba bean mixture, and the trapping was conducted in 12 plots, 2 traps per plot as in 1985. Half of the traps were operated within isolators $57 \mathrm{~cm}$ in diameter, $30 \mathrm{~cm}$ high, buried $20 \mathrm{~cm}$ deep into the soil, covered with an insect net (see Helenius 1991b for description and for some results from oats).

In the 1988 to 1991 experiment, one hectare of spring barley, as a monocrop or undersown with ryegrass or clover (1988 to 1991), or spring wheat, was used for studying the possibility of enhancement of carabids by undersowing in ce- 


\section{Helenius, J. et al. Ground beetle diversity}

reals (Holopainen and Helenius 1992, Helenius and Tolonen 1994, Helenius 1995, Helenius et al. 1995). Altogether, 48 traps in 1988, 32 traps in 1989 (half of which were within plots of $2 \mathrm{~m}$ $\times 3 \mathrm{~m}$ enclosed by plastic sheet, $10 \mathrm{~cm}$ high, buried $2 \mathrm{~cm}$ into the soil), and 32 traps in 1990 and 1991 were operated.

The Viikki-II data of 1978 and 1979 are from a faunistic study by Varis et al. (1984) and by Holopainen and Varis (1986). One cabbage field, one sugar beet field, and one timothy field in Viikki Experimental Farm were included. Each field was sampled by 64 traps $(4 \times 16$ trap set $)$ in 1978 and by 32 traps $(4 \times 8$ trap set $)$ in 1979 . Every fourth trap was filled with a formalin medium; otherwise dry traps were used. The traps were emptied every two to four days. Half of the traps were operated inside $10 \mathrm{~m} \times 10 \mathrm{~m}$ plots (16 traps per plot in 1978 and 8 traps per plot in 1979) surrounded by $35 \mathrm{~cm}$ high and $15 \mathrm{~cm}$ deep plastic barriers in order to restrict the movement of carabids into and from the plots (for details, see Varis et al. 1984, and Holopainen and Varis 1986).

The Viikki-II data of 1982, 1984 and 1985 are from studies by Varis and Tolonen (unpublished M.Sc. thesis by Timo Tolonen, University of Helsinki 1990), in which carabids were studied as predators of cabbage root flies in Viikki Experimental Farm. The crops were monocropped white cabbage or white cabbage undersown with subterranean clover. The carabids were trapped in 1982 in 6 plots, and in the other years in 4 plots by 6 traps per plot. In 1984 and 1985 half of the traps were within enclosures of steel strips $10 \mathrm{~cm}$ high, $5 \mathrm{~cm}$ deep into soil.

\section{Identification of species}

Identification keys by Lindroth (1985, 1986) were used, and the nomenclature follows the enumeration by Silfverberg (1992). Only adult specimens were included. The members of the research teams did taxonomic work. Coleoptera specialists were consulted in a few unclear cas- es. For the Jokioinen data, specimens of the genus Amara were not identified to species level, and for the SW Finland data, only A. aulica, A. eurynota and A. plebeja were identified to species level. Authors of the scientific names of the species are given in Appendix 1.

\section{Meteorological data}

Cumulative day degrees (DD, in ${ }^{\circ} \mathrm{C}$ above $5^{\circ} \mathrm{C}$ ) were calculated as thermal windows of trapping (Table 1). By definition (Finnish Meteorological Institute) the accumulation of DD starts in spring as the mean daily temperature at $2 \mathrm{~m}$ height above ground is permanently above $5^{\circ} \mathrm{C}$, and the snow cover is less than $50 \%$. We used the standard DD statistics from the Finnish Meteorological Institute. The DD data for each pitfall study was obtained from a meteorological station closest to the site. The stations do not measure heat sums at ground level, which would be more directly interpreted as conditions experienced by the carabids. However, the thermal windows are better related to phenology of poikilotherms than calendar dates, especially for comparison of sites latitudinally far from each other (e.g. snow melts a month later in the most northern sites than in the most southern sites).

\section{Data analysis}

The data are from several independent studies, with variable pitfall trapping methods, in variable crops and 14 variable growing seasons in several widely distributed locations. Each of these factors is confounded with all or many of the other factors. From the first to the last study, a period of 17 years is covered. No assumptions are made concerning possible trends in diversity during this time. As a consequence of this heterogeneity, the data are used only to obtain an overall picture of the diversity of ground beetles in Finnish arable land, rather than to attempt to deepen our understanding about their ecology and function in agroecosystems. 
Vol. 10 (2001): 261-276.

Ranks of the species abundances were calculated as means over the relative $(\%)$ catches in the six data sets. Among the top 30 species in rank abundance, rank frequencies were compared. These were calculated as ranks in the incidence, or occurrence in the samples of the pooled data. For further comparison, abundance ranks based on total catch of the species in the pooled data were also calculated. Estimate of Gamma $(\gamma)$ diversity is the total number of species caught $(\mathrm{S})$.

Shannon-Wiener H' (see Southwood 1978) was used as a robust and general Alpha $(\alpha)$ diversity index for the local assemblages represented by the six sets of data:

$$
\text { (1) } \mathrm{H}^{\prime}=\sum_{\mathrm{p}_{\mathrm{i}} \ln \mathrm{p}_{\mathrm{i}}} \text {, }
$$

where $\mathrm{p}_{\mathrm{i}}$ is $\mathrm{N}_{\mathrm{i}} / \mathrm{N}$ ( $\mathrm{N}$ stands for total catch of individuals) for species i. H' was calculated in three different ways, first with Amara-specimens identified to species level, then with Amara excluded, and finally, with Amara sp. at genus level. The last two allowed calculation of the index also for the Jokioinen and the SW Finland data sets. Interpretation of $\mathrm{H}^{\prime}$ in this study must be done bearing in mind that the 'local assemblage' refers to ground beetle communities sampled in each of the individual studies. Thus, due to pooling in each of the data sets, H's do not refer to ecologically meaningful entities (which would be assemblages, or communities, at the same time in the same site). Evenness associated to $\mathrm{H}^{\prime}$, was calculated as J' (= H'/lnS).

Rarefaction (Simberloff 1978, see also Kouki and Haila 1985, Duelli et al. 1999) was used to further study the structure of the assemblages: this method models how species are accumulated with increasing number of individuals caught in the trapping. For any sample size (n) smaller than the original sample $\mathrm{N}(\mathrm{n}<\mathrm{N})$, the expected number of species $E\left(S_{n}\right)$ is calculated as:

$$
E\left(S_{n}\right)=\sum_{i=1}^{S}\left\{1-\frac{\left(\begin{array}{c}
N-N_{i} \\
n
\end{array}\right)}{\left(\begin{array}{l}
N \\
n
\end{array}\right)}\right\}
$$

where $\mathrm{N}_{\mathrm{i}}$ is the number of individuals of species $i$ in the original sample. It should be noted that neither rarefaction curves nor H' use identities of species: in an extreme case, two samples rarefied to the same number of individuals may have the same number of species, but none of the same species. Similarly, two samples may have the same H', without sharing the same species.

For comparison of similarities between the different data sets at the level of species' identities, two Beta $(\beta)$ diversity indices were calculated (Wolda 1981). Jaccard index is indicative of similarity of the species lists only, ignoring the evenness component. Thus, this index is sensitive to species numbers, to the chance event of getting a high number of low frequency species in the catch:

\section{(3) $\quad \mathrm{Cj}=\mathrm{j} /(\mathrm{a}+\mathrm{b}-\mathrm{j})$}

where $\mathrm{j}$ is the number of species common to the two samples, and a and $b$ are respectively the total number of species in each sample (Southwood 1978). The other index, Czekanowski-S $\varnothing$ rensen-Renkonen's (subsequently referred to as Renkonen's index) percentage similarity PS is not dependent on species numbers, being sensitive to the evenness component of $\alpha$-diversity:

$$
\mathrm{PS}=\sum \min \left(\mathrm{p}_{1 \mathrm{i}}, \mathrm{p}_{2 \mathrm{i}}\right)
$$

where $p_{i}$ is the proportion of the species $i$ in the total catch in data sets 1 and 2 (Wolda 1981). For all the diversity indices, Viikki I data were sorted to exclude samples from the plots in which beetle movement had been experimentally manipulated, giving 62 species from a catch of 31934 specimens in this sub sample. This precaution reduced the estimated value of H', for example, by only 0.01 to 0.02 units.

$\mathrm{Cj}$ and $\mathrm{PS}$ were also calculated from sub-sets of data within the same thermal window of DDrange $20.2-580.6^{\circ} \mathrm{C}$, set by the narrowest window of the data sets, that of Outokumpu. This was done in order to allow phenologically more realistic comparison than the comparisons be- 


\section{Helenius, J. et al. Ground beetle diversity}

tween the original data sets with variable trapping times and variable thermal periods.

\section{Results}

Altogether, 111 species of Carabidae were identified from the total of 97799 specimens determined to species level, in the total catch of 99459 beetles (Table 3, Appendix 1). This gives an average catch rate of 1.08 ground beetles per trap day.

Order of H' values were not sensitive to the inclusion or exclusion of Amara sp. at the genus level. The values of H' ranged from 2.32 to 2.97 in the three data sets with all species identified (Table 3). The highest alpha-diversity H', but with relatively low evenness J' values, were from cabbage and sugar beet crops of Viikki II data (Table 3).

Number of species in the data sets ranged from 45 to 82 . As a cautious, conservative rule of thumb (in judging from the rarefaction curves), Finnish crop fields typically harbor carabid communities of at least 30 to 40 species. Rarefied to sample size of 600 individuals
Table 4. Expected number of species E(S) of carabids rarefied to sample size of 600 individuals. Examples from northern and southern spring cereal fields, and southern row crop fields. (SD standard deviation)

\begin{tabular}{lllc}
\hline Sub-set of data & field crop & E(S) & SD \\
\hline Outokumpu 1990 & barley & 30.6 & 2.12 \\
Outokumpu 1991 & barley & 32.2 & 2.11 \\
Viikki I 1990 & barley & 25.6 & 1.78 \\
Viikki I 1991 & barley & 23.2 & 1.86 \\
Viikki II 1978 & cabbage & 34.8 & 1.84 \\
Viikki II 1979 & cabbage & 33.9 & 2.12 \\
Viikki II 1978 & sugar beet & 37.7 & 1.82 \\
Viikki II 1979 & sugar beet & 29.2 & 1.15 \\
\hline
\end{tabular}

(which is sufficiently small sample to include all our data sets), expected species number was in every case over 20 species (Fig. 2). Expected species number at 600 individuals in northern (Outokumpu) barley crops was 31 and 32 species, 5 and 9 species more than in southern (Viikki) barley crops in 1990 and 1991, respectively (Table 4, Fig. 2a-b). With this sampling effort, highest expected species number was found from Viikki cabbage and sugar beet (Fig. 2c) crops in 1978 and 1979 (Table 4).

The five most abundant species accounted for $41.96 \%$ of the total catch in the pooled data

Table 3. Number of Carabidae species, number of identified specimens, total catch, $\alpha$-diversity index H', and evenness index (J'). Because for two of the data sets (Jokioinen and SW Finland), no data of Amara at species level were available, H' and J' are calculated in three versions: first, with Amara species included, then by excluding the genus, and last, by including the genus. (The data sets are in approximate order from North to South: Siilinjärvi-Outokumpu-Jokioinen-SW FinlandViikki I-Viikki II.)

\begin{tabular}{|c|c|c|c|c|c|c|c|}
\hline \multirow[t]{2}{*}{ Summary statistics } & \multicolumn{6}{|c|}{ Data set } & \multirow[t]{2}{*}{ Total } \\
\hline & Sii & Out & Jok & $\mathrm{S}-\mathrm{W}$ Fi & Viik-I & Viik-II & \\
\hline Number of species & 45 & 51 & n.a. & n.a. & 65 & 82 & 111 \\
\hline (excluding Amara species) & (33) & (39) & $(27)$ & (39) & $(47)$ & $(61)$ & (84) \\
\hline No. of specimens identified to species & 8722 & 7160 & 9844 & 11453 & 35908 & 24712 & 97799 \\
\hline Total catch & 8722 & 7160 & 10660 & 11860 & 36339 & 24718 & 99459 \\
\hline \multicolumn{8}{|l|}{ Shannon-Wiener H' (and J' for row 1.) } \\
\hline 1. with Amara identified & 2.32 & 2.67 & n.a. & n.a. & 2.53 & 2.97 & . \\
\hline (evenness J') & $(0.34)$ & $(0.37)$ & n.a. & n.a. & $(0.31)$ & $(0.33)$ & \\
\hline 2. with Amara excluded & 2.28 & 2.57 & 2.41 & 2.59 & 2.40 & 2.77 & \\
\hline 3. with Amara at genus level & 2.30 & 2.62 & 2.53 & 2.67 & 2.49 & 2.78 & \\
\hline
\end{tabular}




\section{AGRICULTURAL AND FOOD SCIENCE IN FINLAND}

Vol. 10 (2001): 261-276.
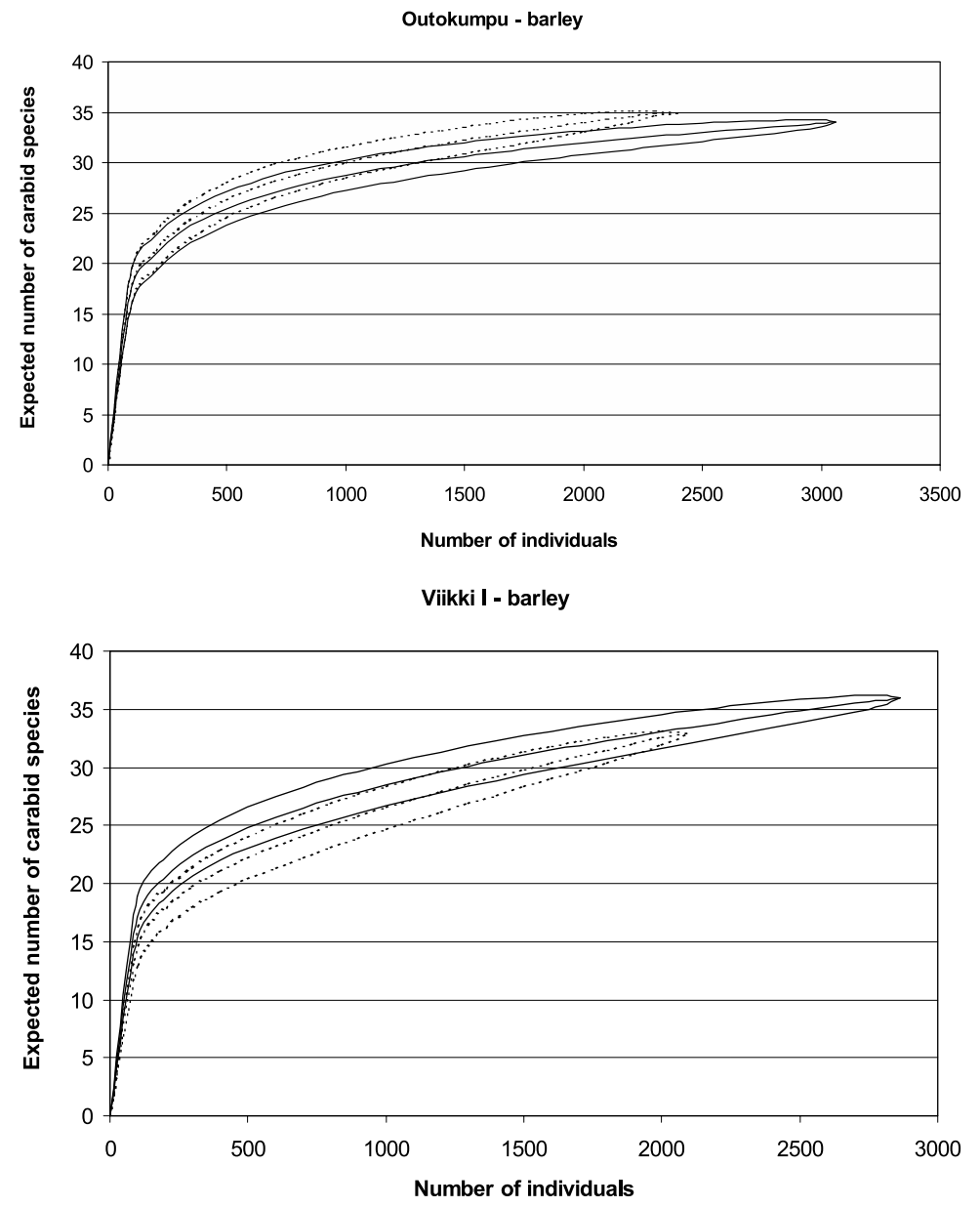

Viikki II - sugar beet

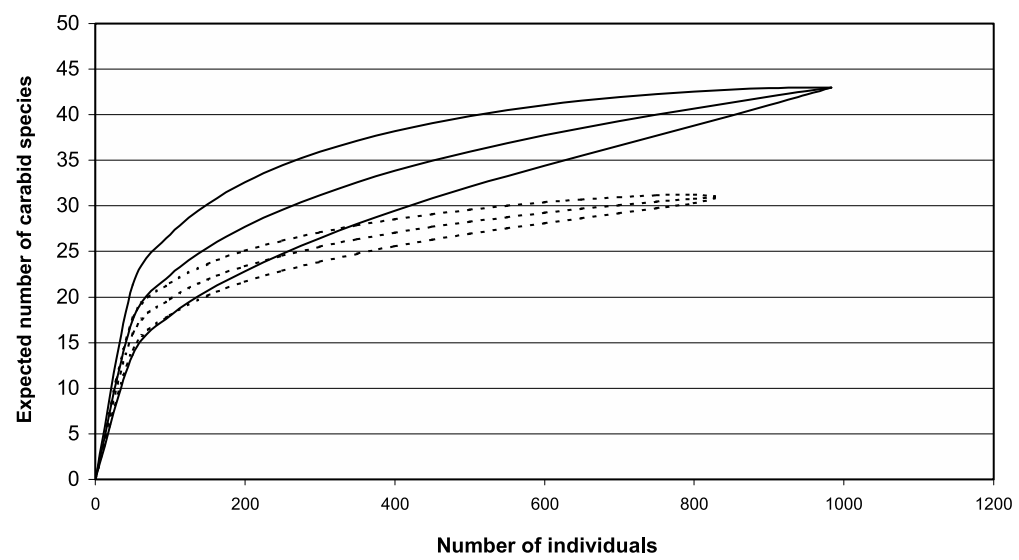

Fig. 2. Expected (rarefied) species number against number of individuals caught in pitfalls in Outokumpu and Viikki I spring barley crops (solid line 1990, dashed line 1991), and in Viikki II sugar beet (solid line 1978, dashed line 1979). (The middle line is the mean, and the upper and lower lines are + and - SD, respectively). 


\section{AGRICULTURAL AND FOOD SCIENCE IN FINLAND}

\section{Helenius, J. et al. Ground beetle diversity}

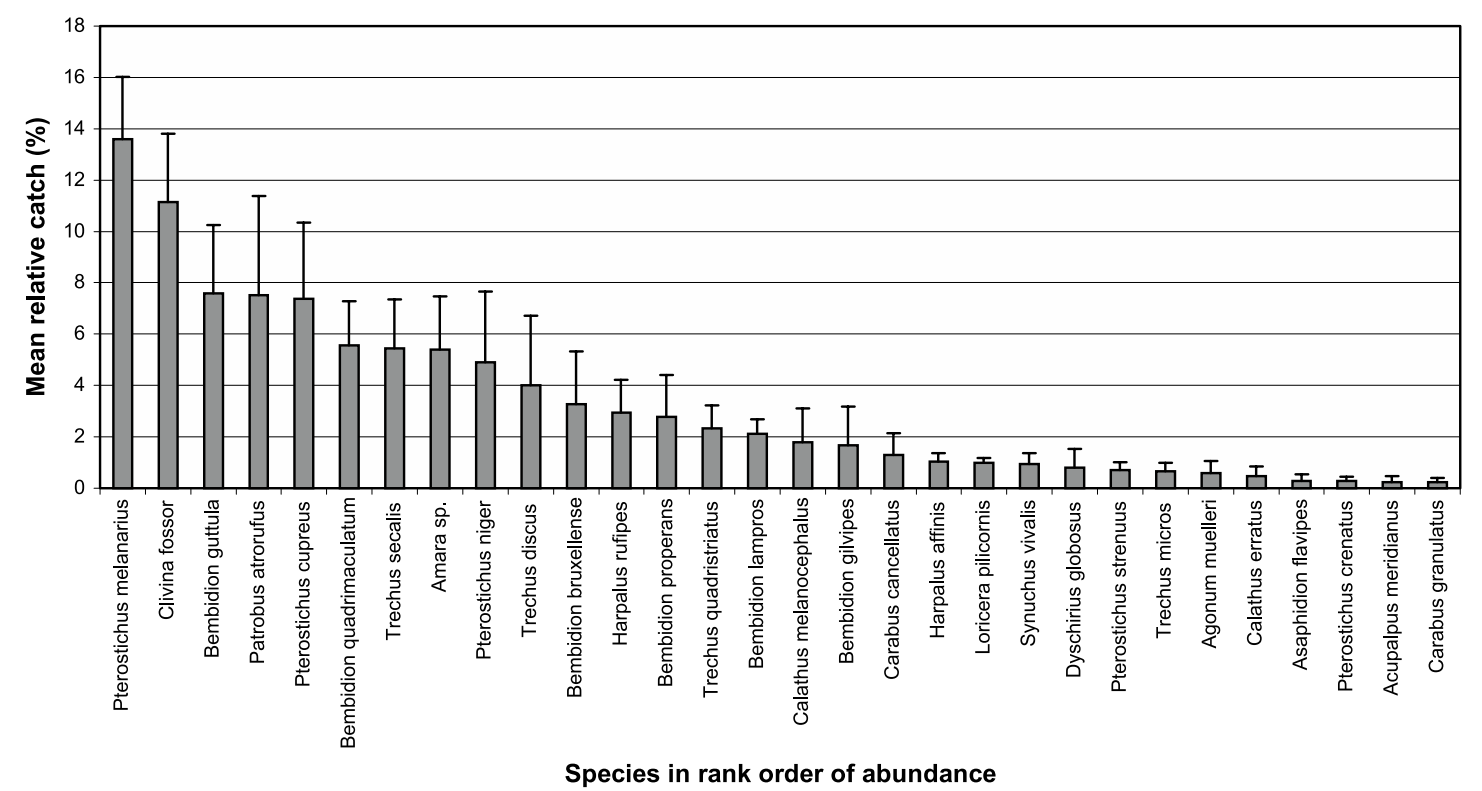

Fig. 3. Relative abundance (\% in catch), as mean of the proportions of total catches in pitfalls over the six data sets, against rank in the mean relative abundance. (Thirty most abundant species. Error bars: SE).

(Fig. 3). These were, in terms of means of the relative catch over the data sets, in rank order Pterostichus melanarius, Clivina fossor, Bembidion guttula, Patrobus atrorufus, and Pterostichus cupreus (Table 5). Trechus secalis and T. discus ranked among the top five in abundance in the pooled data, but not quite in terms of mean relative abundance. They were numerous in the large data set (high total catch) of Viikki I. These species were all included in the list of only 17 species that were shared by all the data sets. The 17 species (numbered 1-10, 12-15, 19-21, 23 in Table 5) were also among the thirty most abundant species. Among the top 30 species, two species were present in the two northern data sets only. These were Carabus cancellatus and Agonum muelleri. Another two species were missing from both northern data sets: these were Trechus micros and Acupalpus meridianus. Top 30 species made up $97.86 \%$ of the total catch (Table 5, Fig. 3).

The most frequently collected species was C. fossor (Table 5), which was found in $11.7 \%$ of samples of the pooled data. The ranks in fre- quencies roughly followed the ranks in mean relative abundance (Fig. 4). Notably more frequent than numerous, i.e. common but not abundant species within the top 30 were Harpalus rufipes and T. micros. Among the numerous but not as frequent species were $P$. atrorufus, $P$. cupreus, $P$. niger, B. bruxellense, B. gilvipes, Agonum muelleri and $P$. crenatus, in order of rank in abundance (Fig. 4).

Percentage similarities (PS) of the species assemblages ranged from $48.4 \%$ between the two Viikki data sets, to only $16.4 \%$ between the northern Siilinjärvi data from cereals and the very southern (coastal) Viikki II data including row crops. Jaccard's $\mathrm{Cj}$ of similarity between species lists varied less, and ranged from 0.39 between the previous two data sets, to 0.55 between the two northern sets from cereals, namely Siilinjärvi and Outokumpu. Notably, as for PS, $\mathrm{Cj}$ was also high between the two Viikki data sets (Table 6). Positive correlation between $\mathrm{Cj}$ and PS was weak $\left(\mathrm{R}^{2}=0.54, \mathrm{P}=0.095\right)$. Phenologically more realistic comparison (subsets of data from the same early season thermal win- 
Vol. 10 (2001): 261-276.

Table 5. Thirty most abundant species numbered in rank order of mean relative pitfall catch calculated over the data sets (first two columns, see also Fig. 3). Ranks in the data sets (in approximate order from north to south) Siilinjärvi-Outokumpu-Jokioinen-SW Finland-Viikki I-Viikki II, and mean over these ranks (nc stands for 'not caught', i.e. absent from the data set) (middle columns). Species' share in the total catch (pooled data) and rank in this share (two columns next to the last column). Ranks in frequency (presence-absence) in pitfall samples at level of the pooled data (last column). Note: Amara sp. at genus level, due to incomplete data of species in two of the subsets of data (Jokioinen and SW Finland).

\begin{tabular}{|c|c|c|c|c|c|}
\hline \multirow{2}{*}{$\begin{array}{l}\text { Top } 30 \text { species in rank order of } \\
\text { mean relative abundance }\end{array}$} & \multirow{2}{*}{$\begin{array}{l}\text { Abundance ranks in } \\
\text { the data sets }\end{array}$} & \multirow[b]{2}{*}{ mean rank } & \multicolumn{2}{|c|}{ Total catch: } & \multirow{2}{*}{$\begin{array}{l}\text { Ranks in } \\
\text { frequency }\end{array}$} \\
\hline & & & $\%$ & rank & \\
\hline 1. Pterostichus melanarius & $2-4-3-2-1-10$ & 3.7 & 13.38 & 1. & 3. \\
\hline 2. Clivina fossor & $6-1-11-1-3-2$ & 4.0 & 12.64 & 2. & 1. \\
\hline 3. Bembidion guttula & $11-6-2-4-4-36$ & 10.5 & 6.74 & 5. & 4. \\
\hline 4. Patrobus atrorufus & $1-7-14-3-14-12$ & 8.5 & 4.90 & 7. & 11. \\
\hline 5. Pterostichus cupreus & $4-5-1-7-22-46$ & 14.2 & 4.30 & 10. & 15. \\
\hline 6. Bembidion quadrimaculatum & $15-3-9-6-10-7$ & 8.3 & 4.84 & 8. & 7. \\
\hline 7. Trechus secalis & $14-22-8-5-5-3$ & 9.5 & 7.27 & 3. & 5. \\
\hline 8. Amara sp.* & $16-11-5-10-7-1$ & 8.3 & 6.61 & 6. & 2. \\
\hline 9. Pterostichus niger & $3-21-6-9-15-22$ & 12.7 & 3.23 & 12. & 16. \\
\hline 10. Trechus discus & $8-20-19-13-2-19$ & 13.5 & 7.10 & 4. & 8. \\
\hline 11. Bembidion bruxellense & 5-2-nc-14-29-24 & . & 1.65 & 16. & 20. \\
\hline 12. Harpalus rufipes & $23-18-13-11-6-6$ & 12.3 & 4.56 & 9. & 6. \\
\hline 13. Bembidion properans & $28-12-21-21-8-4$ & 15.7 & 4.08 & 11. & 10. \\
\hline 14. Trechus quadristriatus & $21-34-7-15-9-8$ & 15.7 & 2.82 & 14. & 9. \\
\hline 15. Bembidion lampros & $17-10-15-8-16-9$ & 12.5 & 2.04 & 15. & 13. \\
\hline 16. Calathus melanocephalus & 27-28-nc-23-13-5 & . & 2.88 & 13. & 12. \\
\hline 17. Bembidion gilvipes & nc-24-4-18-nc-41 & . & 1.08 & 20. & 25. \\
\hline 18. Carabus cancellatus & 7-9-nc-nc-nc-nc & . & 0.63 & 23. & 22. \\
\hline 19. Harpalus affinis & $25-17-17-12-17-13$ & 16.8 & 1.15 & 18. & 18. \\
\hline 20. Loricera pilicornis & $13-13-12-20-18-16$ & 15.3 & 0.84 & 21. & 19. \\
\hline 21. Synuchus vivalis & $10-30-24-17-11-18$ & 18.3 & 1.39 & 17. & 17. \\
\hline 22. Dyschirius globosus & nc-8-26-24-25-35 & . & 0.38 & 25. & 23. \\
\hline 23. Pterostichus strenuиs & $19-15-10-16-35-30$ & 20.8 & 0.45 & 24. & 24. \\
\hline 24. Trechus micros & nc-nc-22-19-12-17 & . & 1.12 & 19. & 14. \\
\hline 25. Agonum mиelleri & 9-16-nc-nc-nc-nc & . & 0.30 & 28. & 34. \\
\hline 26. Calathus erratus & nc-35-28-28-19-11 & . & 0.70 & 22. & 21. \\
\hline 27. Asaphidion flavipes & 30-14-nc-27-29-46 & . & 0.14 & 35. & 28. \\
\hline 28. Pterostichus crenatus & 12-19-nc-25-26-46 & . & 0.16 & 31. & 35. \\
\hline 29. Acupalpus meridianus & nc-nc-nc-34-24-14 & . & 0.35 & 26. & 30. \\
\hline 30. Carabus granulatus & 24-30-15-nc-38-41 & . & 0.14 & 34. & 29. \\
\hline Total & & & $97.86 \%$ & & \\
\hline \multicolumn{6}{|l|}{ * of which the most abundant: } \\
\hline Amara bifrons & 42.79 & & & & \\
\hline A. apricaria & 9.18 & & & & \\
\hline A. plebeja & 5.17 & & & & \\
\hline A. communis & 3.96 & & & & \\
\hline A. aulica & 3.64 & & & & \\
\hline A. municipalis & 2.69 & & & & \\
\hline In all from total of Amara sp. & $67.42 \%$ & & & & \\
\hline
\end{tabular}




\section{Helenius, J. et al. Ground beetle diversity}

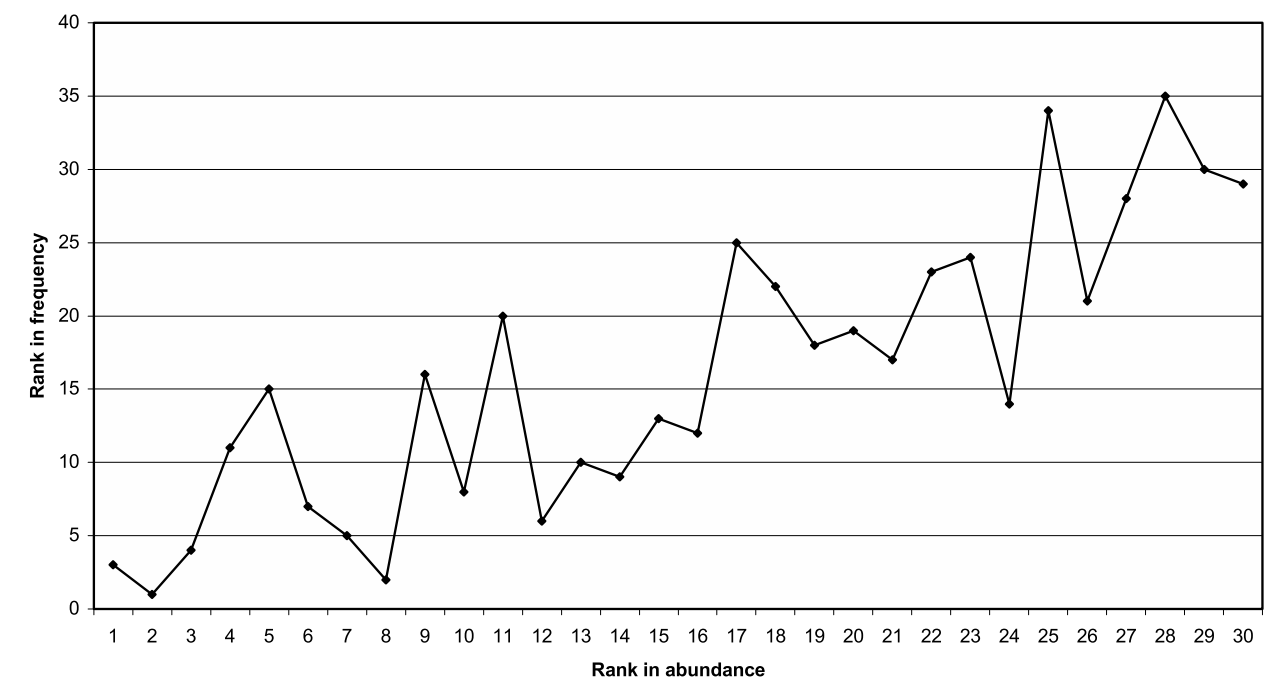

Fig. 4. Rank in frequency (occurrence or incidence in samples) against rank in mean relative abundance of the thirty most abundant species in the pooled data. (Species' order as in Fig. 3, and in Table 5.)

Table 6. Similarity (beta-diversity) indices of Jaccard (Cj: above the diagonal) and Renkonen (PS-\%: below the diagonal) for the data sets (including only the sets for which all the specimens, including Amara sp., were identified to species level). For a phenologically adjusted comparison, index values are also given for early season sub-sets of data set by Outokumpu day-degree (DD) window (in parentheses: including catches at DD range 20.2-580.6)

\begin{tabular}{lllll}
\hline Data set: & Siilinjärvi & Outokumpu & Viikki I & Viikki II \\
\hline Siilinjärvi & ----------- & 0.55 & 0.40 & 0.39 \\
Outokumpu & 44.3 & ----------- & $0.44(0.45)$ & $0.39(0.46)$ \\
Viikki I & 35.7 & $44.2(48.2)$ & --------- & $0.54(0.58)$ \\
Viikki II & 16.4 & $33.7(39.1)$ & $48.4(52.7)$ & ----------- \\
\hline
\end{tabular}

dow defined by DD sums) increased PS values by a mean of $4.6 \%$-units (SD 0.85 ), and $\mathrm{Cj}$ values by 0.04 (SD 0.03) (Table 6), but did not change the order in the comparison.

\section{Discussion}

For a reliable diversity estimate, sampling should access all species equally and in proportion of their population densities. Pitfall trapping meas- ures a combination of density and activity of the individuals, and even trappability may vary between species and be sensitive to slight modifications of the trap design (see e.g. Greenslade 1964, Holopainen 1992, Sundarland et al. 1995). On the other hand, pitfall trapping is cheap and effective in collecting large numbers over short periods of time. Most importantly, pitfall trapping is by far the most frequently used method in even ecological studies of ground beetles (Kromp 1999), its shortcomings are known, and in many cases, activity density is exactly what is needed, especially for studies concerning func- 
Vol. 10 (2001): 261-276.

tional diversity of this family. In estimating spider diversity by four different methods, Coddington et al. (1996) found that each method collected clearly different set of species. Future studies of carabid diversity would benefit from such a comparison of sampling methods. Here, we discuss our results keeping in mind that the estimates are specific to pitfall sampling.

Our estimate of regional (or Gamma) diversity of farmland carabids in Finland was 111 species. Six more species would be added from a total pitfall sample of 36675 beetles from farmland around Lammi Biological Station in southern Finland in 1991-1996, analyzed by Kinnunen et al. (1996, 2001), and Kinnunen and Tiainen (1999). The 117 species is $40 \%$ of carabid species found in Finland, including forests and all other habitats (Lindroth 1985, 1986).

The alpha-diversities calculated from our data (from pooled samples) do not refer to genuine local communities in one place and time. However, the H' values may be used as rough indices of richness and evenness of the assemblages sampled. We present these in order to allow comparison to possible further monitoring studies, which may conveniently be based on meta-analysis of several data sets, as in this study.

Using rarefaction, we came up with an estimate of at least 30 to 40 species in an ordinary agricultural field in Finland. This would include all species from the early season ones (adult overwinterers) to late season ones (larval overwinterers). Duelli et al. (1999), using sophisticated extrapolation from rarefaction curves, report estimates of $37.9 \pm 5.6(\mathrm{SD})$ and $43.1 \pm 6.8$ species in winter wheat and maize in Switzerland. They sampled by funnel-type pitfalls, which are more efficient than cup type ones (Obrist and Duelli 1996). Their estimates as well as the rarefaction curves they present are remarkably close to the ones we report here. We consider these estimates being conservative rather than liberal. Exhaustive sampling would result in higher estimates: Kinnunen et al. (Heidi Kinnunen, Seppo Rekolainen and Maximillian Posch, manuscript: see Kinnunen 1999) trapped
18724 carabid beetles with 900 pitfalls in 45 days in a one hectare plot within a bare fallow field, and caught 60 species.

Boreal coniferous forests dominate Finnish landscapes. Fields are embedded in the taiga. In comparison to rarefaction curves for carabid beetle assemblages in the southern Finnish taiga, provided by Niemelä et al. (1990), the curves for the assemblages in the agricultural fields indicate more species rich and more even communities. For a sample of 100 individuals from a forest community, ca. 10 species were found (Niemelä et al. 1990), whereas in our samples from agricultural land, the same effort would yield twice as many species. Rarefied species number for 600 individuals ranged from $16.6 \pm$ 0.5 species to $20.6 \pm 0.6$ species in forests (Niemelä et al. 1990), again almost only half of the values in our data. Why should agricultural fields have higher diversity than successionally mature, relatively stable and undisturbed forests? Although the analysis is outside the scope of this paper, we suggest the contemporary disturbance (non-equilibrium) theory to be applicable. It explains how richness may peak at intermediate level of disturbance frequency (Bagon et al. 1996, p. 813-827, 908-912 and references therein. See also Pachepsky et al. 2001). Agricultural fields are not in a succession and they are predictable habitats. Although 'disturbed', the disturbance pattern is rather stable irrespective of crop rotation ('same procedure as last year', concerning ploughing, sowing etc.).

Percentage similarities measured by Renkonen PS among the data sets were in every case lower (always less than 50\%) than those reported from forest communities (usually $50 \%$ or higher: Niemelä et al. 1990). Assemblages are more variable in fields than in forests. This is in agreement with Kinnunen (1999, p. 10), who concludes: "In forests (...) communities of nearby sites were very similar. The fields instead seem to support less predictable communities." Again, the disturbance theory provides a way to understand the pattern.

Communities of carabids in surrounding forest patches provide a source of immigrants into 


\section{Helenius, J. et al. Ground beetle diversity}

fields. $24(70.6 \%)$ of the 34 species found by Niemelä et al. (1990) were also included in our list. Effect of drawing from a same regional pool may best (and in agreement with disturbance theory and the patch-dynamics concept) explain why relatively high similarity (by both $\mathrm{Cj}$ and PS) was associated with regional closeness (the two northern data sets, vs. the two southern data sets), rather than to same or similar (as a habitat) agricultural crops. Our data are only indicative in this respect, but in full agreement with Kinnunen et al. (2001) who found that carabid communities varied significantly among patches of farmland but not between fields of different crops within the patches. This and formerly published research strongly suggest that it is the landscape level of spatial hierarchy at which carabids form communities, and at field or crop level, patterns are less clear and the carabids appear as random assemblages (Thiele 1977, Burel 1989, Burel and Baudry 1995, Östman et al. 2001, see also Kromp 1999, Kinnunen 1999).

Carabids are a species rich family in farmland. Their activity-densities are high throughout growing season. As generalists they are not dependent on any pest species as prey: they are always present in the fields, and may contribute to natural control of pests as a buffer against invaders. Economic significance of the group would become obvious only if carabids were missing from the crop fields (see Helenius 1990 for a result of ca. $20 \%$ yield reduction in oats, following only partial removal of carabids).

Because of their diversity and potential role as beneficials, we suggest including carabids into monitoring of biodiversity in agroecosystems. In designing such schemes, we suggest landscape level sampling frames, rather than randomly choosing individual fields for sampling. Pitfall sampling has an advantage of being much used, which eases comparisons to earlier studies.

Acknowledgements. We would like to thank Virpi Vorne for collating the data and Lauri Jauhiainen for programming for the rarefaction. Also, our thanks are due to Arja Vasarainen, Timo Tolonen, Ilpo Mannerkoski, Ilpo Rutanen and many others who helped collect the raw material and in compiling the data. The study was financed by public grants from the Academy of Finland, by Ministry of Agriculture and Forestry, and by a private grant to Juha Helenius from the Finnish Entomological Society.

\section{References}

Ahti, T., Hämet-Ahti, L. \& Jalas, J. 1968. Vegetation zones and their sections in northwestern Europe. Annales Botanici Fennici 5: 169-211.

Bagon, M., Harper, J.L. \& Townsend, C.R. 1996. Ecology. Individuals, populations and communities. $3^{\text {rd }} \mathrm{Ed}$. Blackwell Science, Oxford. 1068 p.

Burel, F. 1989. Landscape structure effects on carabid beetles spatial patterns in western France. Landscape Ecology 2: 215-226.

- \& Baudry, J. 1995. Species biodiversity in changing agricultural landscapes: a case study in the Pays d'Auge France. Agriculture, Ecosystems and Environment 55: 193-200.

Coddington, J.A., Young, L.H. \& Coyle, F.A. 1996. Estimating spider species richness in a southern Appalachian cove hardwood forest. The Journal of Arachnology 24: 111-128.

Duelli, P. Obrist, M.K. \& Schmatz, D.R. 1999. Biodiversity evaluation in agricultural landscapes: above ground insects. Agriculture, Ecosystems and Environment 74: 33-64.
Greenslade, P.J.M. 1964. Pitfall trapping as a method for studying populations of Carabidae (Coleoptera). Journal of Animal Ecology 33: 301-310.

Helenius, J. 1990. Effect of epigeal predators on infestation by the aphid Rhopalosiphum padi and on grain yield of oats in monocrops and mixed intercrops. Entomologia experimentalis et applicata 54:225-236.

- 1991a. Insect numbers and pest damage in intercrops vs. monocrops: concepts and evidence from a system of faba bean, oats and Rhopalosiphum padi (Homoptera, Aphididae). Journal of Sustainable Agriculture 1: 57-80.

- $\quad 1991 \mathrm{~b}$. Integrated control of Rhopalosiphum padi, and the role of epigeal predators in Finland. IOBC /WPRS Bulletin 14: 123-130.

- 1995. Rate and local scale spatial pattern of adult emergence of the generalist predator Bembidion guttula in an agricultural field. Acta Jutlandica 70, 2: 101111.

-, Holopainen, J., Muhojoki, M., Pokki, P., Tolonen, T. \& Venäläinen, A. 1995. Effect of undersowing and green 
Vol. 10 (2001): 261-276.

manuring on abundance of ground beetles (Coleoptera, Carabidae) in cereals. Acta Zoologica Fennica 1996: 156-159.

- \& Tolonen, T. 1994. Enhancement of generalis aphid predators in cereals: effect of green manuring on recruitment of ground beetles (Col., Carabidae). IOBC / WPRS Bulletin 17: 201-210.

Holopainen, J.K. 1992. Catch and sex ratio of Carabidae (Coleoptera) in pitfall traps filled with ethylene glycol or water. Pedobiologia 36: 257-261.

-, Bergman, T., Hautala, E.L. \& Oksanen, J. 1995. The ground beetle fauna (Coleoptera: Carabidae) in relation to properties and foliar fluoride content in spring cereals. Pedobiologia 39: 193-206.

- \& Helenius, J. 1992. Gut contents of ground beetles (Col., Carabidae), and activity of these and other epigeal predators during an outbreak of Rhopalosiphum padi (Hom., Aphididae). Acta Agriculturae Scandinavica 42: 57-61.

- \& Varis, A.-L. 1986. Effects of mechanical barrier and formalin preservative on pitfall catches of carabid beetles (Coleoptera, Carabidae) in arable fields. Journal of Applied Entomology 102: 440-445.

Hughes, R.D. 1959. The natural mortality of Erioischia brassicae (Bouché) (Diptera, Anthomyiidae) during the egg stage of the first generation. Journal of Animal Ecology 28: 343-357.

Huusela-Veistola, E. 1996. Effects of pesticide use and cultivation techniques on ground beetles (Col., Carabidae) in cereal fields. Annales Zoologici Fennici 33: 197-205.

- 2000. Effects of pesticide use and perennial grass strips on arthropod fauna in northern field ecosystems. Annales Universitatis Turkuensis Ser. All Tom. 130. $95 \mathrm{p}$.

Kinnunen, H. 1999. In search of spatial scale - Carabid beetle communities in agricultural landscapes. A PhD dissertation, Department of Ecology and Systematics, University of Helsinki. Helsinki.

-, Järveläinen, K., Pakkala, T. \& Tiainen, J. 1996. The effects of isolation on the occurrence of farmland carabids in a fragmented landscape. Annales Zoologici Fennici 33: 165-171.

- \& Tiainen, J. 1999. Carabid distribution in a farmland mosaic: the effect of patch type and location. Annales Zoologici Fennici 36: 149-158.

-, Tiainen, J. \& Tukia, H. 2001. Farmland carabid beetle communities at multiple levels of spatial scales. Ecography 24: 189-197.

Kouki, J. \& Haila, Y. 1985. Lajimäärä, näytekoko ja rarefaktio - lajimäärän vertailun ongelma. Luonnon Tutkija 89: 156-159.

Kromp, B. 1999. Carabid beetles in sustainable agriculture: a review on pest control efficacy, cultivation impacts and enhancement. Agriculture, Ecosystems and Environment 74: 187-228.

Lindroth, C.H. 1985. The Carabidae (Coleoptera) of Fennoscandia and Denmark. Fauna Entomologica Scandinavica $15,1.225 \mathrm{p}$.

- 1986. The Carabidae (Coleoptera) of Fennoscandia and Denmark. Fauna Entomologica Scandinavica 15, 2. $497 \mathrm{p}$.
Lövei, G.L. \& Sunderland, K.D. 1996. Ecology and behaviour of ground beetles (Coleoptera: Carabidae). Annual Review of Entomology 41: 231-256.

Niemelä, J., Haila, Y., Halme, E., Pajunen, T. \& Punttila, P. 1990. Diversity variation in carabid beetle assemblages in the southern Finnish taiga. Pedobiologia 34: 1-10.

Obrist, M.K. \& Duelli, P. 1996. Trapping efficiency of funnel- and cup-traps for epigeal arthropods. Mitteilungen den Schweizerischen Entomologischen Geschellshaft 69: 361-369.

Östman, Ö., Ekbom, B., Bengtsson, J. \& Weibull, A.-C. 2001. Landscape complexity and farming practice influence the condition of polyphagous carabid beetles. Ecological Applications 11: 480-488.

Pachepsky, E., Crawford, J.W., Brown, J.L. \& Squire, G. 2001. Towards a general theory of biodiversity. Nature 410: 923-926.

Potts, G.R. \& Vickerman, G.P. 1974. Studies on the cereal ecosystem. Advances in Ecological Research 8: 107-197.

Silfverberg, H. 1992. Enumeratio Coleopterorum Fennoscandiae, Daniae et Baltiae. Helsinki, Helsingin Hyönteisvaihtoyhdistys.

Simberloff, D. 1978. Use of rarefaction and related methods in ecology. In: Dickson, K.L. et al. (eds.). Biological Data in Water Pollution Assessment: Quantitative and Statistical Aanalyses. ASTM STP 652, American Society for Testing and Materials, p. 150-165.

Southwood, T.R.E. 1978. Ecological methods. Chapman and Hall. London, New York. 524 p.

Sunderland, K.D., De Snoo, G.R., Dinter, A., Hance, T., Helenius, J., Jepson, P., Kromp, B., Lys, J.-A., Samu, F., Sotherton, N.W., Toft, S. \& Ulber, B. 1995. Density estimation for invertebrate predators in agroecosystems. Acta Jutlandica 70, 2: 133-162.

Thiele, H.-U. 1977. Carabid beetles in their environments. Springer Verlag, Berlin. $396 \mathrm{p}$.

Varis, A.-L. 1982. Insekticidernas effect på carabidpredatorerna av kålflugor. Integrerad bekämpning I grönsaker på friland med särskild hänblick på skadedjur, NJF Seminarium nr. 31. p. 25.

- 1989. Cabbage field Carabidae (Coleoptera) and their role as natural enemies of Delia radicum and D. floralis (Diptera, Anthomyiidae). Acta Entomologica Fennica 53: 61-63.

-, Holopainen, J.K. \& Koponen, M. 1984. Abundance and seasonal occurrence of adult Carabidae (Coleoptera) in cabbage, sugar beet and timothy fields in southern Finland. Zeitschrift für angewandte Entomologie 98: 62-73.

Vasarainen, A. \& Kurppa, S. 1996. Vegetation and carabid fauna affected by conventional and biological cultivation. In: Proceedings of the 20th International Congress of Entomology, Firenze, Italy, 25-31 August 1996. p. 661.

Wishart, G., Doane, F.J. \& Maybee, G.E. 1956. Notes on beetles as predators of eggs of Hylemya brassicae (Bouché) (Diptera, Anthomyiidae). Canadian Entomologist 88: 634-639.

Wolda, H. 1981. Similarity indices, sample size and diversity. Oecologia 50: 296-302. 


\title{
SELOSTUS
}

\section{Maakiitäjäisten lajimonimuotoisuus suomalaisilla peltoviljelmillä}

\author{
Juha Helenius, Jarmo K. Holopainen, Erja Huusela-Veistola, Sirpa Kurppa, Pia Pokki ja Anna-Liisa Varis \\ Helsingin yliopisto ja MTT (Maa- ja elintarviketalouden tutkimuskeskus)
}

\begin{abstract}
Maakiitäjäisten lajimonimuotoisuutta suomalaisilla peltoviljelmillä selvitettiin kuudesta toisistaan riippumattomasta tutkimuksesta, joista vanhin oli vuodelta 1978 ja uusin vuodelta 1994. Kuoppa-ansapyynnillä koottu aineisto käsitti 97799 maakiitäjäisyksilöä, jotka määritettiin 111 lajiin. Shannonin-Wienerin diversiteetti-indeksin $\mathrm{H}^{\prime}$ arvo oli tyypillisesti noin 2,5. Kuudensadan yksilön otoskokoon rarefoitu, odotettavissa oleva lajimäärä yksittäiseltä peltolohkolta oli noin 30 lajia. Viisi runsainta lajia muodostivat $42 \%$ ja 30 runsainta lajia $98 \%$ koko yksilömäärästä. Lajimäärän ja runsaussuhteet huomioon ottava Renkosen prosentuaalisen samankaltaisuuden indeksi PS sai arvoja $16 \%$ samankaltaisuudesta aina $48 \%$ samankaltaisuuteen osa-aineistojen välillä. Samalta maantieteelliseltä alueelta pyydetyt aineistot olivat kasvustotyypistä riippumatta samankaltaisempia kuin eri alueilta pyydetyt aineistot.
\end{abstract}

Suomessa pellot ovat tyypillisesti ainakin osittain metsien ympäröimiä. Verrattuna metsälajistosta julkaistuihin tietoihin, peltomaiden maakiitäjäisyhteisöt ovat lajirikkaampia, ja niissä lajien väliset runsaussuhteet ovat tasaisempia kuin metsien maakiitäjäisyhteisöissä. Tarkastelemme tätä yhteisöekologisen häiriöteorian valossa, jonka mukaan yhteisöjen lajidiversiteetit ovat korkeimmillaan kohtuullisesti (keskinkertaisen usein) häirityissä elinympäristöissä.

Tuloksemme korostavat viljelyalueen (alue-ekologisen tason) merkitystä lohkotason tai viljelykasvilajin sijasta, pyrittäessä ymmärtämään viljelymaiden maakiitäjäisdiversiteetin vaihtelua paikasta toiseen. Ehdotamme, että maakiitäjäislajistot otetaan mukaan maatalousympäristön biodiversiteetin seurantaan, ja että seuranta näiden osalta järjestettäisiin viljelyalueiden mittakaavassa. 


\section{Appendix 1}

Species of Carabidae and their total catch using pitfall-traps. Thermal window of Day Degrees (DD. above $5^{\circ} \mathrm{C}$ ) of trapping, as well as DD range in which the species was trapped. The DD range gives an indication of thermal activity range, but is artificially limited by the period of pitfall trapping (see also Table 1). (Note: '0' denotes not caught, '-' denotes not identified).

\begin{tabular}{|c|c|c|c|c|c|c|c|c|}
\hline \multirow[t]{2}{*}{ Species } & \multirow{2}{*}{$\begin{array}{c}\mathrm{Sii} \\
74.3- \\
876.9\end{array}$} & \multirow{2}{*}{$\begin{array}{l}\text { Out } \\
20.2- \\
580.6\end{array}$} & \multirow{2}{*}{$\begin{array}{c}\text { Jok } \\
18.8 \\
-1106.9\end{array}$} & \multirow{2}{*}{$\begin{array}{c}\text { SW Fin } \\
81.9 \\
510.9\end{array}$} & \multirow{2}{*}{$\begin{array}{c}\text { Viik I } \\
40.7 \\
1533.8\end{array}$} & \multirow{2}{*}{$\begin{array}{c}\text { Viik II } \\
8.1 \\
1362.4\end{array}$} & \multicolumn{2}{|c|}{ DD range: } \\
\hline & & & & & & & $\min$ & $\max$ \\
\hline Acupalpus meridianus (Linnaeus) & 0 & 0 & 0 & 6 & 14 & 332 & 66.5 & 849.3 \\
\hline A. parvulus (Sturm) & 0 & 0 & 0 & 0 & 5 & 28 & 87.4 & 529.9 \\
\hline Agonum fuliginosum (Panzer) & 41 & 0 & 0 & 0 & 0 & 3 & 74.3 & 876.9 \\
\hline A. gracile Sturm & 0 & 0 & 0 & 13 & 0 & 0 & 231.5 & 483.3 \\
\hline A. micans Nicolai & 1 & 0 & 0 & 0 & 0 & 0 & 74.3 & 876.9 \\
\hline A. muelleri (Herbst) & 245 & 53 & 0 & 0 & 0 & 0 & 32.7 & 876.9 \\
\hline A. piceum (Linnaeus) & 0 & 9 & 0 & 0 & 0 & 0 & 69 & 400.7 \\
\hline A. sexpunctatum (Linnaeus) & 47 & 16 & 0 & 0 & 0 & 0 & 74.3 & 876.9 \\
\hline Amara aenea (Degeer) & 5 & 7 & - & - & 0 & 9 & 74.3 & 1007.3 \\
\hline A. apricaria (Paykull) & 3 & 14 & - & - & 480 & 106 & 56.6 & 1320.9 \\
\hline A. aulica (Panzer) & 3 & 4 & - & 5 & 73 & 154 & 74.3 & 1160.3 \\
\hline A. bifrons (Gyllenhal) & 14 & 8 & - & - & 236 & 2554 & 8.1 & 1257.1 \\
\hline A. brunnea (Gyllenhal) & 0 & 0 & - & - & 0 & 1 & 970.8 & 1028.4 \\
\hline A. communis (Panzer) & 3 & 21 & - & - & 3 & 233 & 8.1 & 1127 \\
\hline A. consularis (Duftschmid) & 0 & 0 & - & - & 29 & 50 & 168.3 & 1238 \\
\hline A. convexiuscula (Marsham) & 0 & 0 & - & - & 0 & 16 & 413.5 & 1040.2 \\
\hline A. curta Dejean & 0 & 1 & - & - & 3 & 0 & 85.6 & 807.7 \\
\hline A. cursitans Zimmermann & 0 & 0 & - & - & 0 & 1 & 1136.6 & 1169.7 \\
\hline A. equestris (Duftschmid) & 0 & 0 & - & - & 7 & 2 & 168.3 & 965.1 \\
\hline A. eurynota (Panzer) & 1 & 0 & - & 23 & 115 & 33 & 61.6 & 1320.9 \\
\hline A. famelica Zimmermann & 2 & 2 & - & - & 20 & 0 & 74.3 & 883.1 \\
\hline A. familiaris (Duftschmid) & 0 & 17 & - & - & 7 & 3 & 88 & 715.4 \\
\hline A. fulva (Müller) & 0 & 0 & - & - & 8 & 110 & 134 & 1195.5 \\
\hline A. gebleri Dejean & 0 & 1 & - & - & 0 & 0 & 231.2 & 313.5 \\
\hline A. ingenua (Duftschmid) & 0 & 0 & - & - & 2 & 172 & 193.9 & 1227.4 \\
\hline A. littorea Thomson & 0 & 0 & - & - & 0 & 1 & 1136.6 & 1169.7 \\
\hline A. lunicollis Schiödte & 0 & 8 & - & - & 1 & 2 & 102.2 & 764 \\
\hline A. majuscula (Chaudoir) & 0 & 0 & - & - & 7 & 39 & 115.8 & 1205.4 \\
\hline A. montivaga Sturm & 0 & 0 & - & - & 1 & 2 & 58.3 & 444 \\
\hline A. municipalis (Duftschmid) & 0 & 0 & - & - & 1 & 176 & 328.7 & 1257.1 \\
\hline A. nitida Sturm & 1 & 0 & - & - & 0 & 0 & 74.3 & 876.9 \\
\hline A. ovata (Fabricius) & 2 & 0 & - & - & 1 & 2 & 74.3 & 876.9 \\
\hline A. plebeja (Gyllenhal) & 23 & 101 & - & 9 & 207 & 0 & 35.9 & 1257.1 \\
\hline A. quenseli (Schönherr) & 1 & 0 & - & - & 0 & 0 & 74.3 & 876.9 \\
\hline A. similata (Gyllenhal) & 2 & 6 & - & - & 0 & 5 & 35.9 & 952 \\
\hline Amara sp. & 0 & 0 & 745 & 293 & 371 & 5 & 18.8 & 1533.8 \\
\hline Anchomenus dorsalis (Pontoppidan) & 0 & 0 & 0 & 1 & 53 & 132 & 58.3 & 1197.8 \\
\hline Anisodactylus binotatus (Fabricius) & 0 & 1 & 0 & 0 & 0 & 0 & 313.5 & 400.7 \\
\hline Asaphidion flavipes (Linnaeus) & 1 & 110 & 0 & 18 & 6 & 3 & 20.2 & 876.9 \\
\hline A. pallipes (Duftschmid) & 0 & 12 & 0 & 0 & 1 & 162 & 135.1 & 1040.2 \\
\hline Badister bullatus (Schrank) & 0 & 0 & 0 & 0 & 0 & 1 & 328.7 & 358.5 \\
\hline B. lacertosus Sturm & 0 & 0 & 0 & 0 & 1 & 0 & 152.6 & 206.9 \\
\hline Bembidion biguttatum (Fabricius) & 0 & 0 & 0 & 2 & 0 & 0 & 287.1 & 472.8 \\
\hline B. bruxellense Wesmaël & 390 & 928 & 0 & 202 & 6 & 111 & 20.2 & 970.8 \\
\hline B. femoratum Sturm & 6 & 0 & 0 & 0 & 0 & 75 & 74.3 & 1147.9 \\
\hline
\end{tabular}


Appendix 1

continued from the preceding page

\begin{tabular}{|c|c|c|c|c|c|c|c|c|}
\hline \multirow[t]{3}{*}{ Species } & \multirow{3}{*}{$\begin{array}{c}\text { Sii } \\
74.3- \\
876.9\end{array}$} & \multirow{3}{*}{$\begin{array}{c}\text { Out } \\
20.2- \\
580.6\end{array}$} & \multirow{3}{*}{$\begin{array}{c}\text { Jok } \\
18.8 \\
-1106.9\end{array}$} & \multirow{3}{*}{$\begin{array}{c}\text { SW Fin } \\
81.9 \\
510.9\end{array}$} & \multirow{3}{*}{$\begin{array}{c}\text { Viik I } \\
40.7 \\
1533.8\end{array}$} & \multirow{3}{*}{$\begin{array}{c}\text { Viik II } \\
8.1 \\
1362.4\end{array}$} & \multicolumn{2}{|c|}{ DD range: } \\
\hline & & & & & & & $\min$ & $\max$ \\
\hline & & & & & & & & \\
\hline B. gilvipes Sturm & 0 & 12 & 976 & 79 & 0 & 5 & 18.8 & 1106.9 \\
\hline B. guttula (Fabricius) & 112 & 668 & 1938 & 1019 & 2957 & 11 & 18.8 & 1320.9 \\
\hline B. lampros (Herbst) & 53 & 227 & 121 & 393 & 363 & 874 & 8.1 & 1533.8 \\
\hline B. nigricorne Gyllenhal & 0 & 0 & 0 & 0 & 3 & 0 & 180.6 & 395.8 \\
\hline B. properans (Stephens) & 2 & 131 & 38 & 57 & 1217 & 2614 & 16.6 & 1533.8 \\
\hline B. quadrimaculatum (Linnaeus) & 61 & 876 & 341 & 964 & 1011 & 1561 & 8.1 & 1533.8 \\
\hline B. tetracolum Say & 0 & 0 & 0 & 0 & 0 & 2 & 18.8 & 934.3 \\
\hline Bembidion sp. & 0 & 0 & 6 & 0 & 54 & 0 & 728.6 & 1227.4 \\
\hline Bradycellus caucasicus Chaudoir & 0 & 1 & 0 & 0 & 0 & 4 & 45.7 & 1195.5 \\
\hline B. harpalinus (Audinet-Serville) & 0 & 0 & 0 & 0 & 0 & 3 & 1169.7 & 1227.4 \\
\hline Broscus cephalotes (Linnaeus) & 0 & 0 & 0 & 0 & 2 & 38 & 187.4 & 1147.9 \\
\hline Calathus ambiguus (Paykull) & 0 & 0 & 0 & 0 & 1 & 309 & 271.8 & 1197.8 \\
\hline C. erratus (Sahlberg) & 0 & 2 & 1 & 16 & 97 & 579 & 26 & 1227.4 \\
\hline C. melanocephalus (Linnaeus) & 4 & 7 & 0 & 33 & 808 & 2017 & 26 & 1533.8 \\
\hline C. micropterus (Duftschmid) & 0 & 0 & 0 & 0 & 4 & 0 & 443.7 & 715.4 \\
\hline Carabus cancellatus Illiger & 355 & 270 & 0 & 0 & 0 & 0 & 20.2 & 876.9 \\
\hline C. granulatus Linnaeus & 10 & 5 & 121 & 0 & 2 & 5 & 18.8 & 1106.9 \\
\hline C. hortensis Linnaeus & 0 & 0 & 0 & 0 & 1 & 1 & 830.5 & 1007.3 \\
\hline C. nemoralis Müller & 0 & 0 & 2 & 19 & 8 & 47 & 52.3 & 1362.4 \\
\hline C. violaceus Linnaeus & 0 & 0 & 0 & 0 & 1 & 0 & 810.9 & 934.3 \\
\hline Carabus sp. & 0 & 0 & 2 & 44 & 0 & 0 & 51 & 663.6 \\
\hline Clivina fossor (Linnaeus) & 366 & 1073 & 202 & 2073 & 5819 & 3041 & 8.1 & 1533.8 \\
\hline Cychrus caraboides (Linnaeus) & 0 & 0 & 0 & 0 & 1 & 2 & 248.9 & 1177.3 \\
\hline Dicheirotrichus rufithorax (Sahlberg) & 0 & 0 & 0 & 0 & 0 & 7 & 231.4 & 911.5 \\
\hline Dromius sigma (Rossi) & 0 & 0 & 3 & 4 & 0 & 5 & 26 & 483.5 \\
\hline Dyschirius globosus (Herbst) & 0 & 316 & 2 & 32 & 13 & 13 & 20.2 & 799.8 \\
\hline D. politus (Dejean) & 0 & 0 & 0 & 0 & 0 & 3 & 134 & 483.5 \\
\hline D. thoracicus (Rossi) & 0 & 7 & 0 & 0 & 0 & 0 & 83.9 & 400.7 \\
\hline Dyschirius sp. & 0 & 0 & 41 & 0 & 0 & 0 & 18.8 & 1106.9 \\
\hline Elaphrus riparius (Linnaeus) & 1 & 12 & 0 & 0 & 0 & 1 & 74.3 & 876.9 \\
\hline Elaphrus sp. & 0 & 0 & 0 & 5 & 0 & 0 & 95.2 & 455.1 \\
\hline Harpalus affinis (Schrank) & 8 & 36 & 102 & 219 & 253 & 522 & 29.4 & 1320.9 \\
\hline H. latus (Linnaeus) & 0 & 5 & 68 & 57 & 4 & 10 & 18.8 & 1047.3 \\
\hline H. luteicornis (Duftschmid) & 0 & 0 & 0 & 0 & 1 & 0 & 87.4 & 127.2 \\
\hline H. quadripunctatus Dejean & 1 & 0 & 0 & 0 & 3 & 15 & 74.3 & 1195.5 \\
\hline H. rufipes (Degeer) & 19 & 28 & 133 & 243 & 2245 & 1866 & 52.3 & 1533.8 \\
\hline H. tardus (Panzer) & 0 & 0 & 0 & 0 & 0 & 6 & 66.7 & 586.5 \\
\hline Harpalus sp. + Ophonus sp. & 0 & 0 & 2 & 28 & 2 & 0 & 187.4 & 716.3 \\
\hline Lebia chlorocephala (Hoffmannsegg) & 0 & 1 & 0 & 1 & 0 & 0 & 273.2 & 523.8 \\
\hline Leistus ferrugineus (Linnaeus) & 0 & 0 & 0 & 0 & 0 & 6 & 735.7 & 1227.4 \\
\hline L. terminatus (Hellwig) & 0 & 1 & 5 & 0 & 16 & 27 & 145 & 1320.9 \\
\hline Leistus sp. & 0 & 0 & 0 & 0 & 1 & 0 & 715.4 & 792.4 \\
\hline Loricera pilicornis (Fabricius) & 71 & 125 & 136 & 74 & 210 & 224 & 16.6 & 1320.9 \\
\hline Microlestes minutulus (Goeze) & 0 & 0 & 0 & 9 & 53 & 17 & 133.5 & 846.5 \\
\hline Notiophilus aquaticus (Linnaeus) & 0 & 0 & 0 & 0 & 0 & 74 & 16.6 & 1301.2 \\
\hline N. palustris (Duftschmid) & 0 & 0 & 0 & 4 & 0 & 1 & 231.5 & 1227.4 \\
\hline Notiophilus sp. & 0 & 0 & 1 & 0 & 0 & 0 & 1663.6 & 822.6 \\
\hline Olisthopus rotundatus (Paykull) & 0 & 0 & 0 & 15 & 0 & 0 & 95.2 & 232 \\
\hline
\end{tabular}

continued on the next page 
Appendix 1

continued from the preceding page

\begin{tabular}{|c|c|c|c|c|c|c|c|c|}
\hline \multirow[t]{2}{*}{ Species } & \multirow{2}{*}{$\begin{array}{c}\text { Sii } \\
74.3- \\
876.9 \\
\end{array}$} & \multirow{2}{*}{$\begin{array}{c}\text { Out } \\
20.2- \\
580.6 \\
\end{array}$} & \multirow{2}{*}{$\begin{array}{c}\text { Jok } \\
18.8 \\
-1106.9 \\
\end{array}$} & \multirow{2}{*}{$\begin{array}{c}\text { SW Fin } \\
81.9 \\
510.9 \\
\end{array}$} & \multirow{2}{*}{$\begin{array}{c}\text { Viik I } \\
40.7 \\
1533.8\end{array}$} & \multirow{2}{*}{$\begin{array}{c}\text { Viik II } \\
8.1 \\
1362.4\end{array}$} & \multicolumn{2}{|c|}{ DD range: } \\
\hline & & & & & & & $\min$ & $\max$ \\
\hline Oodes helopioides (Fabricius) & 0 & 1 & 0 & 0 & 0 & 0 & 250.6 & 335.2 \\
\hline Ophonus nitidulus Stephens & 0 & 0 & 0 & 0 & 0 & 1 & 444.2 & 496.7 \\
\hline O. puncticollis (Paykull) & 0 & 0 & 0 & 0 & 5 & 5 & 196.5 & 846.5 \\
\hline O. rufibarbis (Fabricius) & 0 & 0 & 0 & 1 & 0 & 84 & 134 & 1169.7 \\
\hline Patrobus assimilis Chaudoir & 0 & 0 & 0 & 0 & 1 & 0 & 135.3 & 180.6 \\
\hline P. atrorufus (Ström) & 2230 & 376 & 124 & 1156 & 457 & 532 & 20.2 & 1502.7 \\
\hline Platynus livens (Gyllenhal) & 0 & 0 & 0 & 0 & 1 & 0 & 538.7 & 566 \\
\hline P. obscurus (Herbst) & 0 & 0 & 0 & 13 & 0 & 0 & 226.7 & 483.3 \\
\hline Pterostichus crenatus (Duftschmid) & 96 & 27 & 0 & 19 & 12 & 3 & 52.3 & 1070.1 \\
\hline P. cupreus (Linnaeus) & 758 & 739 & 2064 & 693 & 19 & 3 & 18.8 & 1533.8 \\
\hline P. melanarius (Illiger) & 1650 & 761 & 1409 & 2042 & 6630 & 811 & 18.8 & 1533.8 \\
\hline P. minor (Gyllenhal) & 0 & 0 & 96 & 0 & 0 & 0 & 18.8 & 1076.2 \\
\hline P. niger (Schaller) & 1556 & 21 & 668 & 386 & 448 & 134 & 58.3 & 1320.9 \\
\hline P. nigrita (Paykull) & 0 & 5 & 0 & 0 & 0 & 0 & 76.3 & 197.9 \\
\hline P. oblongopunctatus (Fabricius) & 31 & 0 & 0 & 10 & 0 & 2 & 29.4 & 876.9 \\
\hline P. strenuиs (Panzer) & 44 & 59 & 219 & 90 & 3 & 31 & 16.6 & 1227.4 \\
\hline Pterostichus sp. & 0 & 0 & 17 & 0 & 0 & 0 & 66.7 & 997.6 \\
\hline Stomis pumicatus (Panzer) & 0 & 0 & 0 & 0 & 0 & 3 & 328.7 & 448.6 \\
\hline Syntomus foveatus (Geoffroy) & 0 & 0 & 0 & 0 & 0 & 1 & 248.9 & 288.1 \\
\hline S. truncatellus (Linnaeus) & 0 & 0 & 0 & 0 & 0 & 150 & 8.1 & 1147.9 \\
\hline Synuchus vivalis (Illiger) & 123 & 5 & 4 & 81 & 989 & 183 & 74.3 & 1502.7 \\
\hline Trechus discus (Fabricius) & 272 & 23 & 87 & 217 & 6292 & 171 & 74.3 & 1533.8 \\
\hline T. micros (Herbst) & 0 & 0 & 27 & 75 & 809 & 199 & 40.7 & 1320.9 \\
\hline T. quadristriatus (Schranck) & 36 & 3 & 592 & 124 & 1041 & 1004 & 18.8 & 1533.8 \\
\hline T. rubens (Fabricius) & 1 & 0 & 0 & 0 & 7 & 0 & 74.3 & 1030 \\
\hline T. secalis (Paykull) & 69 & 18 & 365 & 993 & 2814 & 2967 & 18.8 & 1533.8 \\
\hline Trechus sp. & 0 & 0 & 2 & 0 & 3 & 1 & 305.3 & 1106.9 \\
\hline Trichocellus placidus (Gyllenhal) & 2 & 0 & 0 & 0 & 0 & 1 & 16.6 & 876.9 \\
\hline
\end{tabular}

